\title{
若年女性の瘦身志向が食行動と疲労に与える影響
}

重田 公子*1*2 ·笹田 陽子*1*3 · 鈴木 和春*4 · 樫村 修生*1

(*1東京農業大学大学院農学研究科, *2東横学園女子短期大学,

$* 3$ 盛岡大学短期大学部, $* 4$ 東京農業大学応用生物科学部)

\section{Effects of dieting tendency on the eating behavior and fatigue in young women}

\author{
Kimiko Shigeta $^{* 1, * 2}$, Yoko Sasada ${ }^{* 1, * 3}$, Kazuharu Suzuki*4, Osamu Kashimura*1 \\ ${ }^{*}$ Department of Environmental Symbiotic Biological Science, Graduate School of Agriculture, Tokyo \\ University of Agriculture, 1-1-1 Sakuragaoka Setagaya-ku Tokyo, 156-8502 \\ ${ }^{* 2}$ Toyoko Gakuen Women's College, 8-9-18 Todoroki Setagaya-ku Tokyo, 158-8586 \\ ${ }^{*}$ Morioka Daigaku Junior College, 808 Sunagome Takizawa Iwate, 020-0173 \\ ${ }^{*}$ Faculty of Applied Bioscience, Tokyo University of Agriculture, 1-1-1 Sakuragaoka Setagaya-ku \\ Tokyo, 156-8502

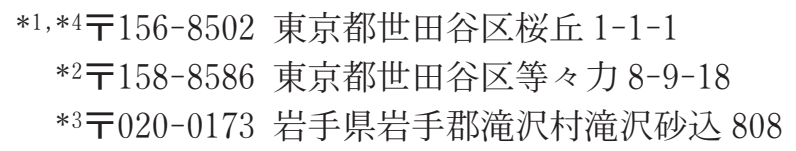

The number of young women who have a tendency toward weight loss despite being underweight or normal with respect to body mass index (BMI) has increased in recent years. The objective of the present study was to elucidate the physical and mental effects of dieting tendency on young women, with a focus on the eating behavior and subjective fatigue symptoms.

1 ) The proportions of underweight, normal, and overweight women with respect to BMI were $17.5 \%, 75.4 \%$, and $7.1 \%$, respectively. However, dieting tendency was observed in $87.9 \%$ of all women. In particular, $92.2 \%$ of women with a dieting tendency were "underweight" or "normal" with respect to BMI.

2 ) Among women with a dieting tendency were "underweight" or "normal" with respect to BMI, $60.3 \%$ had an "overweight" body image of themselves, while $60.9 \%$ had experienced dieting, indicating significant differences between women with and without a dieting tendency in both cases.

3 ) Experience of binge eating was significantly more common in women with a dieting tendency $(53.6 \%)$ than in those without a dieting tendency $(38.0 \%)$.

4 ) Complaint rates for subjective fatigue symptom group I, comprising "sleepiness" and "unsteady gait", were significantly higher in women with a dieting tendency than in those without a dieting tendency. Total complaint rate for fatigue was significantly higher in women with a dieting tendency $(25.9 \%)$ than in those without a dieting tendency $(19.7 \%)$.

\section{緒言}

我々の身近には食を核としたヒトとものとの関わりの 視点での情報が氾濫している。その結果, 特に日本にお
いては「女性は瘦せていなければ魅力的でない」といっ た文化的プレッシャーをメディアが作り出すことで瘦身 志向は高まり1) 3)，ありのままの自分に安心感が持てず 肥満と減量に悩む若い女性が増加している。平成15年国

$164(70)$ 
民健康・栄養調査のボディイメージと栄養摂取に関する 報告によると，20歳代女性の Body Mass Index（BMI） を用いた肥満およびやせの割合は，肥満者 $8.1 \%$ ，低体 重（やせ）者23.1\%で，やせの割合は20年前の同世代 $11.4 \%$ と比べて 11.7 ポイント増加している4)。体重を適 正にコントロールすることは，健康の維持・増進および 生活習慣病予防の観点から大切なことであるが，若年女 性が持つ体型へのこだわりからくる無理な減量は，月経 不順や停止，貧血などの身体異常を引き起こし，さらに

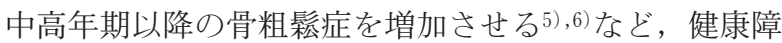
害への影響が指摘されている。厚生省は，21世紀におけ る国民健康づくりの指標とされる「健康日本21」の中で, 若年女性を除く児童や生徒，成人男性および40歳以上の 女性に対しては，生活習慣病予防の観点から肥満者の減 少を目標に掲げているが，20歳代女性には「2010年度を 目途にやせの割合を $15 \%$ 以下に引き下げる」という数值 目標7)を示している。

既に我々は若年女性の減量のための食事制限が健康に 与える影響8) 10)に関する報告をしているが，若年女性 が持つ体重調節意識，すなわち瘦身志向が心身に与える 影響を健康面から検証する報告は少ない。そこで本研究 では，BMIを基準とする体型区分ではやせおよび正常 でありながら，特有の体重調節意識を持つ若年女性の瘦 身志向が心身に与える影響について, 食行動と疲労自覚 症状をもとに明らかにすることを目的とした。

\section{方法}

\section{1. 調査対象}

調査は，都市部の女子短期大学生593人を対象として 実施し，471名（回収率79.4\%）から回答が得られ，記 載もれなど不備な調査票を除く 423 名（有効回答率 89.8 \%) を解析対象者とした。解析対象者の学科構成は，生 活学科 1 年生 102 名. 2 年生 50 名, 栄養学科 1 年生 75 名, 保育学科 1 年生196名で, 食事療法や運動などに関する 専門的な教育は受けていない学生である。

\section{2. 調査時期および調査方法}

調査時期は，平成15年10月から17年11月，全ての調査 票を配布の後，自記式留置法により回収した。調査内容 は，基本的属性 4 項目，身体計測 2 項目，生活時間調査， 体重調節に関する意識と行動 8 項目, 疲労自覚症状しら べ30項目および健康と食生活に関する意識18項目である。 本調査の回答は，全数処理することを前提に予め用意し た選択肢から記号または数字を選んで回答する方法をと ったが，減量のための体重調節の方法については具体的 に記述するように依頼した。集計過程に抢ける調査票の 照合のため本人の承諾を得て記名式で実施し，調査依頼 時には個人情報保護法などにも考慮し，全員に対してイ ンフォームドコンセントを十分に行った。

\section{3. 集計および解析方法}

基本的属性については, 性別, 年齢, 所属学科 ·学年 について記述を依頼した。

身体計測では，身長，体重を測定した。身体的特徵の 評価には，身長（m）と体重（kg）から BMI（体重/身 長 $\left.{ }^{2}\right)$ を算出し, 日本肥満学会肥満症診断基準検討委員 会の判定基準に従って, 低体重（やせ）, 普通体重（正 常)，肥満の 3 群に区分した。

生活時間調査は，授業のある平日 1 日（24時間）を指 定して記録し，記録票を基に身体活動指数抢よび睡眠時 間を算出した。身体活動指数は，1.60未満（代表值1.50） を身体活動レベル I (低い)，1.60以上 1.90 未満（同 1.75）を身体活動レベルII（ふつう），1.90以上 2.20 未 満（同2.00）を身体活動レベルIII（高い）の3 群に分類 した。

体重調節に関する意識と行動については, 瘦身志向, ボディイメージ (体型認識), 理想体重, 理想体型, ダ イエット経験，ダイエット法などについて質問した。瘦 身志向では，「やせたいと思いますか」の問いに対して 4 カテゴリーで回答させ, 「思う, 少し思う」と回答し た者を併せて瘦身志向「あり」群に，「あまり思わない， 思わない」と回答した者を瘦身志向「なし」群の 2 つに 分けて集計した。「理想体型」については，対象者の考 える理想体重および理想体型の人が「いる」「いない」 の 2 カテゴリーで回答させ，「いる」と答えた者には， 具体的に名前と主な活動を記述依頼した。ダイエット経 験については，「ダイエットをしたことがありますか」 の問い対して，3 カテゴリーで回答させ，「何回もした ことがある，1回ある」と回答した者を併せてダイエッ 卜経験「あり」群に，「したことはない」と回答した者 をダイエット経験「なし」群の 2 つに分けて集計した。 ダイエットの方法は，瘦身志向「あり」群で，ダイエッ 卜経験「あり」の者209名に，具体的に複数回答でダイ エット法の記述を依頼した。「ダイエット」とは本来 「日常の食事」「調整された食䬣」と訳される。しかし， 近年では厚生労働省の報告書 ${ }^{6}$, 先行研究7)等に颃いて 「瘦身を目的とする体重調節行動」を「ダイエット」と 記すことがある。本研究に拈ける「ダイエット」とは後 者の意図するものである。

疲労自覚症状調査には, 日本産業衛生協会の調査票 「疲労自覚症状しらべ」を用いた。調査票は, 眠気とだ るさに関する症状群（以下 I 群と表記）, 注意集中の困 難に関する症状群（同 II 群），局在した身体違和に関す る症状群（同正群）の 3 群，計 30 項目から構成され，I から III群の愁訴数を集計し愁訴率で示した。

健康と食生活状況については，健康に対する意識，食 習慣と健康との関連性，自棄食い経験，食生活への配慮， 食事時間の規則性, 契食に要する時間, 欠食行動などに ついて調査した。健康に対する意識については，4 カテ ゴリーで回答させた。「健康に自信がある，少しある」 
と回答した者を併せて「健康に自信あり」群に，「少し ない，ない」と回答した者を「健康に自信なし」群の 2 群に分けて集計した。な推計に際して，欠損值の多い 項目，関連性が認識されない項目は除外した。

瘦身志向の有無と疲労自覚症状しらべ，体重調節に関 する意識抢よび健康と食生活状況との関連の検討につい ては，本来必要のない体重調節をしている者の抱える問 題点を明らかにするために，肥満者を除くやせおよび正 常の393名を調查対象者とした。BMIによる区分および 瘦身志向と調査項目との関連性は， $\mathrm{t}$ 検定または $\chi^{2}$ 検 定を用いて分析し，有意水準は危険率 $5 \%$ 未満とした。

\section{結＼cjkstart果}

\section{1. 基本的属性}

本研究のように，大学生を対象に瘦身志向が心と身体 に与える影響について検討する際には，対象者の専攻学 科による意識の差を考慮に入れる必要がある。そこで, 調查項目と瘦身志向との関連性を専攻学科（生活学科, 栄養学科および保育学科) 別に検討したが，有意差はみ られなかったので，専攻学科を超えて423名（平均年歯 $19.3 \pm 1.0$ 歳）を調査対象者として解析を行った。

\section{2. 体重調節に関する意識と行動}

表 1 には，BMI を基準とする体型区分からみた身長， 体重, BMI，生活時間調査記録から算出した身体活動 指数の平均值および標準偏差を示した。対象者全体の身 体的特徵を表す身長，体重および BMI の平均值と標準 偏差は，それぞれ $158.2 \pm 5.2 \mathrm{~cm} ， 51.9 \pm 7.5 \mathrm{~kg}$ および $20.73 \pm 2.82$ であった。また, BMIによるやせ，正常お よび肥満区分の割合は，順に $17.5 \%, 75.4 \%$ および 7.1 \%で，BMIの区分が「やせ」と「正常」の割合は 92.9 \%に達した。また，体重および BMI の各区分間には有 意差（ $\mathrm{p}<0.01 ）$ が認められた。しかし，身体活動指数

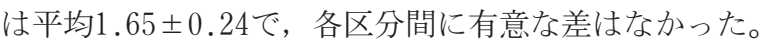

表 2 は，体型区分から見たボディイメージ，対象者の 考える理想体重, 理想体重を基に算出した BMI および 瘦身志向の有無を示した。自分の体型を「太っている」 とイメージしている者の割合は，全体の55.8\%であった。 体型区分では「やせ」であるにもかかわらず $9.4 \%$ は 「太っている」，62.2\%は「普通」と認識していた。対象 者の想定する理想体重と BMI は平均では46.9土4.6kg, BMI $18.72 \pm 1.89$ であるが，体型区分間には有意差（p <0.01）が認められた。さらに, 瘦身志向の有無では, 瘦身志向がある者は $87.9 \%$, 瘦身志向がない者は $12.1 \%$ であった。さらに，BMI 18.5未満のやせ群に抢いて瘦

表 1 体型区分からみた身長, 体重, BMI および身体活動指数

\begin{tabular}{|c|c|c|c|c|c|c|}
\hline 区分 & $\begin{array}{c}\text { 体型基準 } \\
\text { BMI }\end{array}$ & 人数 $(\%)$ & $\begin{array}{l}\text { 身長 } \\
(\mathrm{cm})\end{array}$ & $\begin{array}{l}\text { 体重 } \\
(\mathrm{kg})\end{array}$ & BMI & $\begin{array}{c}\text { 身体活動 } \\
\text { 指数 }\end{array}$ \\
\hline 低体重（やせ） & 18.5未満 & $74(17.5)$ & $158.9 \pm 4.6$ & $44.7 \pm 2.9 \overline{\bar{*}_{* *}}$ & $17.69 \pm 0.65 \overline{7 * *}_{*^{*}}$ & $1.69 \pm 0.27$ \\
\hline 普通体重（正常） & 18.5 以上 25.0 未満 & $319(75.4)$ & $158.1 \pm 5.2$ & $51.9 \pm 5.07_{* *}^{* *}$ & $20.75 \pm 1.617_{* *} *$ & $* 1.65 \pm 0.23$ \\
\hline 肥 満 & 25.0 以上 & $30(7.1)$ & $157.7 \pm 6.2$ & $69.6 \pm 8.9=$ & $27.95 \pm 2.92=$ & $1.59 \pm 0.27$ \\
\hline 平均 & & & $158.2 \pm 5.2$ & $51.9 \pm 7.5$ & $20.73 \pm 2.82$ & $1.65 \pm 0.24$ \\
\hline
\end{tabular}

$\mathrm{BMI}=$ 体重 $/$ 身長 $^{2} ，$ 体重 $(\mathrm{kg}) ，$ 身長 $(\mathrm{m})$ 平均土標準偏差

$* * \mathrm{p}<0.01$

表 2 体型区分からみたボディイメージ, 理想体重およびBMI, 瘦身志向の有無

\begin{tabular}{|c|c|c|c|c|c|c|c|}
\hline \multirow[b]{2}{*}{ 区分 } & \multicolumn{3}{|c|}{ ボディイメージ** } & \multicolumn{2}{|c|}{ 理想 } & \multicolumn{2}{|c|}{ 瘦身志向** } \\
\hline & $\begin{array}{l}\text { 太っている } \\
\text { 人数 }(\%)\end{array}$ & $\begin{array}{c}\text { 普 通 } \\
\text { 人数 }(\%)\end{array}$ & $\begin{array}{l}\text { 瘦せている } \\
\text { 人数 }(\%)\end{array}$ & $\begin{array}{l}\text { 体重 } \\
(\mathrm{kg})\end{array}$ & BMI & $\begin{array}{c}\text { あり } \\
\text { 人数 }(\%)\end{array}$ & $\begin{array}{c}\text { なし } \\
\text { 人数 }(\%)\end{array}$ \\
\hline 低体重（やせ） & $7(9.4)$ & $46(62.2)$ & $21(28.4)$ & $44.3 \pm 3.7 \overline{7_{* *}}$ & $17.59 \pm 1.13 \overline{7_{* *}}$ & $54(73.0)$ & $20(27.0)$ \\
\hline 普通体重（正常） & $200(62.7)$ & $112(35.1)$ & $7(2.2)$ & $46.9 \pm 4.17_{* *}^{* *}$ & $18.74 \pm 1.76\rceil\left._{* *}\right|^{* *}$ & $289(90.6)$ & $30(9.4)$ \\
\hline 肥 満 & $29(96.7)$ & $1(3.3)$ & $0(0.0)$ & $52.5 \pm 6.7=$ & $21.17 \pm 2.41 \beth$ & $29(96.7)$ & $1(3.3)$ \\
\hline 平均 & $236(55.8)$ & $159(37.6)$ & $28(6.6)$ & $46.9 \pm 4.6$ & $18.72 \pm 1.89$ & $372(87.9)$ & $51(12.1)$ \\
\hline
\end{tabular}

平均土標準偏差

体型区分からみた ボディイメージ，瘦身志向～$\chi^{2}$ 検定

$*^{* *} \mathrm{p}<0.01$

166 (72) 
表 3 瘦身志向の有無からみた身体的特徵, 理想体重および BMI

\begin{tabular}{|c|c|c|c|c|c|c|c|c|}
\hline \multirow{2}{*}{ 項 目 } & & & \multirow{2}{*}{ 人数（\%） } & \multirow{2}{*}{$\begin{array}{l}\text { 身 長 } \\
(\mathrm{cm})\end{array}$} & \multirow{2}{*}{$\begin{array}{l}\text { 体 重 } \\
(\mathrm{kg})\end{array}$} & \multirow{2}{*}{ BMI } & \multicolumn{2}{|c|}{ 理想 } \\
\hline & & & & & & & 体重(kg) & BMI \\
\hline \multirow{2}{*}{ 瘦身志向 } & あ & $\eta$ & $343(87.3)$ & $158.2 \pm 5.1$ & $51.1 \pm 5.4$ & $20.40 \pm 1.87 \square$ & $46.5 \pm 4.3$ & $18.60 \pm 1.44$ \\
\hline & な & し & $50(12.7)$ & $158.4 \pm 4.9$ & $46.8 \pm 3.9$ & $18.66 \pm 1.38$ & $46.2 \pm 3.0$ & $18.54 \pm 1.20$ \\
\hline 平 均 & & & $393(100)$ & $158.3 \pm 5.1$ & $50.5 \pm 5.4$ & $20.18 \pm 1.91$ & $46.5 \pm 4.2$ & $18.59 \pm 1.42$ \\
\hline
\end{tabular}

平均 \pm 標準偏差

$* * \mathrm{p}<0.01$

身志向がある者は73.0\%であった。

表 3 は, 身体的特徵, 理想体重および BMI を瘦身志 向の有無で比較した。肥満者を除くやせおよび正常者を 対象者として集計した結果，瘦身志向がある者は調査対 象者の $87.3 \%$ で，瘦身志向がない者は $12.7 \%$ であた。 体重および BMI は，瘦身志向のない者に比較して，瘦 身志向のある者が有意 $(\mathrm{p}<0.01)$ に高い值を示した。 しかし, 瘦身志向がある者と瘦身志向がない者では, 理 想体重は $46.5 \mathrm{~kg}$ と $46.2 \mathrm{~kg}$, BMI は18.60と18.54であり, 両者間に有意な差は認められなかった。

表 4 は, 瘦身志向の有無からみたダイエット経験の有 無およびダイエット経験ありの者のダイエット法を示し た。ダイエット経験ありの者で, 瘦身志向ありの者の割 合は $60.9 \%$, なしの者は $20.0 \%$, 両群間には有意差（p <0.01）が認められた。瘦身志向めりの者でダイエット

\section{表 4 瘦身志向の有無からみたダイエット経験の有無および} ダイエット法

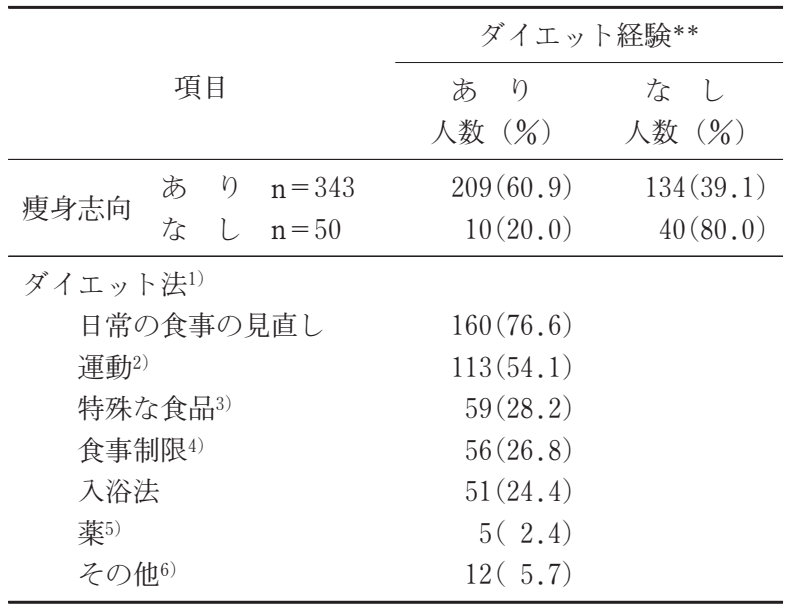

瘦身志向からみたダイエット経験 $\quad \chi^{2}$ 検定

$*^{* *} \mathrm{p}<0.01$

1) 複数回答, ダイエット経験および瘦身志向あり に対する 割合

2）ジョギング，腹筋，縄跳び，軽レジスタンスなど

3）ダイエット食品, 寒天, 豆乳, 酢大豆, ヨーグルト, サプ リメントなど

4) 食事量を減らす, 間食をしない, 決めた時間以降はたべな い, 食事を抜く, 穀類・油脂類の摂取を控えるなど

5）利尿作用や食欲を制御する薬

6) エステなど
経験ありの者が，ダイエット方法を複数回答した結果は, 「日常の食事の見直し」76.6\%，ダイエット食品などの 「特殊な食品」 $28.2 \%$ ，「食事制限」 $26.8 \%$ など食事の内 容やあり方に関するものの他は，「運動」を行う者 54.1 $\%$, 瘦身に効果的な「入浴法」 $24.4 \%$, 「薬」 $2.4 \%$, そ の他 $5.7 \%$ あ゙あた。また，運動とあわせて食事の見直 しや食事制限をすると答えた者も21.9\%含まれていた。

\section{3. 疲労自覚症状と瘦身志向およびダイエット}

表 5 は, 瘦身志向の有無から反た疲労自覚症状を項目 ごとに示した。I群・眠気とだるさに関する症状群の愁 訴「ねむい」に打ける瘦身志向がある者と瘦身志向がな い者の割合は，順に $77.0 \%, 64.0 \%$,「足もとがたより ない」 $7.3 \%, 0 \%$ で, 瘦身志向のある者が有意 $(\mathrm{p}<$ 0.05）に高い割合を示した。しかし， II㧍よび亚群にお ける愁訴は, 瘦身志向がある者と瘦身志向がない者との 間に有意差は認められなかった。

表 6 には, 瘦身志向の有無からみた体型区分, 理想体 重抢よびダイエット経験と疲労愁訴の関連を疲労愁訴率 で示した。

体型区分と瘦身志向との関連においては，体型区分は 正常で，瘦身志向ありの者の疲労愁訴は25.7 $15.6 \%$, 瘦身志向なしの者の $19.4 \pm 11.0 \%$ に比較して 6.3 ポイン 卜高く, 有意差 $(\mathrm{p}<0.05)$ が認められた。また, 瘦身 志向ありの者で, 体型区分は正常の者の疲労愁訴は, や せの者の疲労愁訴 $20.7 \pm 13.1 \%$ に比較して 5.0 ポイント 高く, 両者の間には有意差 $(\mathrm{p}<0.05)$ が認められた。

さらに, 理想体型と瘦身志向との関連においては, 目 標とする理想体重による疲労愁訴の差をみるために体型 区分正常の者を対象とし，理想体型を「やせ」と「正常」 に分けて集計した。瘦身志向ありの者で, 現在の体重よ り平均 $-6.6 \pm 3.6 \mathrm{~kg}$ のせの範囲を理想体型とする者の 疲労愁訴は $30.5 \pm 15.7 \%$, 現在の体重より $-3.9 \pm 3.9 \mathrm{~kg}$ の正常の範囲を理想体型とする者の疲労愁訴 $23.9 \pm 15.0$ \%に比較して，やせの範囲を理想体型とするものが 6.6 ポイント有意 $(\mathrm{p}<0.01)$ に高かった。

また, ダイエット経験と瘦身志向との関連に打いては, 瘦身志向あり・ダイエット経験なしの者の疲労愁訴は, $27.0 \pm 17.7 \%$, 瘦身志向なし・ダイエット経験なしの者 の疲労愁訴 $20.0 \pm 11.8 \%$ に比較して 7.0 ポイント高く, 
日本食生活学会誌 Vol.18 No.2（2007）

表 5 瘦身志向の有無からみた疲労自覚症状

\begin{tabular}{|c|c|c|c|c|c|c|c|c|c|c|c|}
\hline \multirow[b]{3}{*}{ 愁 訴 } & さに関 & 五する症 & 状群 & 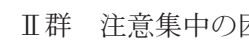 & 困難に| & 関する* & 芷状群 & III群 局在した身价 & 違和に & 関する & 症状群 \\
\hline & \multicolumn{2}{|c|}{ 瘦身志向 } & \multirow[b]{2}{*}{$\begin{array}{c}\text { 検定 }{ }^{1)} \\
\mathrm{p}\end{array}$} & \multirow[b]{2}{*}{ 愁 訴 } & \multicolumn{2}{|c|}{ 瘦身志向 } & \multirow[b]{2}{*}{$\begin{array}{c}\text { 検定 }{ }^{1)} \\
\mathrm{p}\end{array}$} & \multirow[b]{2}{*}{ 愁 訴 } & \multicolumn{2}{|c|}{ 瘦身志向 } & \multirow[b]{2}{*}{$\begin{array}{c}\text { 検定 }^{1)} \\
\mathrm{p}\end{array}$} \\
\hline & $\begin{array}{l}\text { あり } \\
(\%)\end{array}$ & $\begin{array}{l}\text { なし } \\
(\%)\end{array}$ & & & $\begin{array}{l}\text { あり } \\
(\%)\end{array}$ & $\begin{array}{l}\text { なし } \\
(\%)\end{array}$ & & & $\begin{array}{l}\text { あり } \\
(\%)\end{array}$ & $\begin{array}{l}\text { なし } \\
(\%)\end{array}$ & \\
\hline 頭がおもい & 19.0 & 18.0 & 0.872 & 考えがまとまらない & 37.6 & 36.0 & 0.826 & 頭が痛い & 18.1 & 12.0 & 0.289 \\
\hline 全身がだるい & 34.7 & 26.0 & 0.224 & 話をするのがいやになる & 6.7 & 4.0 & 0.464 & 肩がこる & 55.4 & 58.0 & 0.729 \\
\hline 足がだるい & 16.9 & 16.0 & 0.872 & いらいらする & 25.7 & 22.0 & 0.578 & 腰が痛い & 28.9 & 32.0 & 0.649 \\
\hline あくびがでる & 61.8 & 58.0 & 0.606 & 気がちる & 22.4 & 20.0 & 0.697 & いき苦しい & 5.2 & 4.0 & 0.708 \\
\hline 頭がぼんやりする & 46.1 & 36.0 & 0.181 & 物事に熱心になれない & 22.2 & 20.0 & 0.730 & 口がかわく & 22.7 & 12.0 & 0.083 \\
\hline ねむい & 77.0 & 64.0 & $0.047^{*}$ & ちょっとした事が思い出せない & 37.9 & 40.0 & 0.775 & 声がかすれる & 10.5 & 6.0 & 0.321 \\
\hline 目がつかれる & 52.5 & 46.0 & 0.392 & する事に間違いが多くなる & 21.0 & 22.0 & 0.870 & めまいがする & 12.0 & 8.0 & 0.412 \\
\hline 動作がぎこちなくなる & 8.5 & 4.0 & 0.275 & 物事が気にかかる & 22.4 & 28.0 & 0.385 & まぶたや筋肉がピクピクする & 19.0 & 18.0 & 0.872 \\
\hline 足もとがたよりない & 7.3 & 0 & $0.049^{*}$ & きちんとしていられない & 12.2 & 16.0 & 0.457 & 手足がふるえる & 3.2 & 0 & 0.199 \\
\hline 横になりたい & 39.9 & 34.0 & 0.421 & 根気がなくなる & 21.9 & 28.0 & 0.333 & 気分がわるい & 7.9 & 8.0 & 0.975 \\
\hline 平均 & 36.4 & 30.2 & & 平均 & 23.1 & 22.6 & & 平均 & 18.3 & 15.6 & \\
\hline
\end{tabular}

複数回答

1 ）瘦身志向 あり vs なし ${ }^{*} \mathrm{p}<0.05$

表 6 瘦身志向の有無からみた体型区分, 理想体型およびダイエット経験と疲労愁訴の関連

\begin{tabular}{|c|c|c|c|c|c|c|c|c|c|}
\hline & \multirow[b]{2}{*}{ 項 } & \multirow[b]{2}{*}{ 目 } & & \multicolumn{2}{|c|}{ 体型区分 } & \multicolumn{2}{|c|}{ 理想体型1) } & \multicolumn{2}{|c|}{ ダイエット経験 } \\
\hline & & & & $\begin{array}{l}\text { やせ } \\
(\%)\end{array}$ & $\begin{array}{l}\text { 正常 } \\
(\%)\end{array}$ & $\begin{array}{l}\text { やせ } \\
(\%)\end{array}$ & $\begin{array}{l}\text { 正常 } \\
(\%)\end{array}$ & $\begin{array}{l}\text { あり } \\
(\%)\end{array}$ & $\begin{array}{l}\text { なし } \\
(\%)\end{array}$ \\
\hline \multirow[t]{2}{*}{ 瘦身志向 } & あ & り & $\mathrm{n}=343$ & $\stackrel{20.7 \pm 13.1}{L^{2}} *$ & $\underset{*}{25.7 \pm 15.6}$ & $\stackrel{30.5 \pm 15.7}{\llcorner}^{\$ *}$ & $\underset{\sim}{23.9} \pm 15.0^{82}$ & $25.8 \pm 20.3$ & $27.0 \pm 17.7\rceil$ \\
\hline & な & ᄂ & $\mathrm{n}=50$ & $22.7 \pm 21.2$ & $19.4 \pm 11.0$ & $27.3 \pm 20.5^{\S 3}$ & $24.0 \pm 19.6^{\S 4}$ & $25.7 \pm 16.8$ & $20.0 \pm 11.8$ \\
\hline
\end{tabular}

表中の数值は疲労愁訴率の平均土標準偏差

1) 欠損值を含むため $\quad \& 1 \mathrm{n}=111 \quad \& 2 \mathrm{n}=163 \quad{ }^{3} \mathrm{n}=5 \quad \& 4 \mathrm{n}=19$

* $\mathrm{p}<0.05 \quad * * \quad \mathrm{p}<0.01$

表 7 瘦身志向の有無からみた健康および食生活に関する意識

\begin{tabular}{|c|c|c|c|c|c|c|c|c|c|c|}
\hline & \multirow[b]{2}{*}{ 項目 } & & \multicolumn{2}{|c|}{ 健康に対する意識1) } & \multicolumn{2}{|c|}{ 食生活に配慮2) } & \multicolumn{2}{|c|}{ 食事時間の規則性3) } & \multicolumn{2}{|c|}{ 自棄食い経験4)* } \\
\hline & & & $\begin{array}{l}\text { あり } \\
\text { 人 }(\%)\end{array}$ & $\begin{array}{l}\text { な し } \\
\text { 人 }(\%)\end{array}$ & $\begin{array}{l}\text { あり } \\
\text { 人 }(\%)\end{array}$ & $\begin{array}{l}\text { な し } \\
\text { 人 }(\%)\end{array}$ & $\begin{array}{l}\text { 規則的 } \\
\text { 人 }(\%)\end{array}$ & $\begin{array}{l}\text { 不規則 } \\
\text { 人(\%) }\end{array}$ & $\begin{array}{l}\text { あ り } \\
人(\%)\end{array}$ & $\begin{array}{l}\text { な し } \\
\text { 人 }(\%)\end{array}$ \\
\hline \multirow{3}{*}{ 瘦身志向 } & あり & $\mathrm{n}=343$ & $171(50.4)$ & $168(49.6)$ & $197(57.4)$ & $144(42.0)$ & $135(39.4)$ & $204(59.5)$ & $184(53.8)$ & $158(46.2)$ \\
\hline & なし & $\mathrm{n}=50$ & $25(50.0)$ & $25(50.0)$ & $31(62.0)$ & $19(38.0)$ & $19(38.0)$ & $31(62.0)$ & $19(38.0)$ & $31(62.0)$ \\
\hline & & & $196(50.4)$ & $193(49.6)$ & $228(58.3)$ & $163(41.7)$ & $154(39.6)$ & $235(60.4)$ & $203(51.8)$ & $189(48.2)$ \\
\hline
\end{tabular}

人数 $(\%)$

瘦身志向あり群 欠損值を含むため $\quad{ }^{1)} \mathrm{n}=339 \quad{ }^{2)} \mathrm{n}=341 \quad{ }^{3)} \mathrm{n}=339 \quad{ }^{4)} \mathrm{n}=342$

瘦身志向からみた 自棄食い経験 $\chi^{2}$ 検定

$* \mathrm{p}<0.05$

両者の間には有意差 $(\mathrm{p}<0.05)$ が認められた。

\section{4. 健康および食生活に関する意識}

表 7 は, 瘦身志向の有無から久た健康および食生活に 関する意識について示した。瘦身志向がある者において， 健康に自信がある者は50.4\%，自信がない者は $49.6 \%$ で あり, ほぼ半数に分かれた。また, 瘦身志向がない者に
おいても, 健康に自信がある者と自信がない者は, 半数 ずつであった。瘦身志向の有無からみた「食生活に配慮」, 「食事時間の規則性」については，有意差はないが，「食 生活に配慮している」「食事時間は不規則」が多い傾向 を示した。また, 瘦身志向の有無からみた自棄食い経験 がある者の割合は, 瘦身志向がない者 $(38.0 \%)$ に比較 して，瘦身志向がある者 $(53.6 \%)$ の方が有意 $(\mathrm{p}<$ 
0.05）に多かった。

\section{考察}

\section{1. 身体的特徵と身体活動指数}

今回の調査に抢ける対象者の身長，体重抢よび BMI の平均值は，平成15年国民健康 ·栄養調査に打ける同 性・同年齢区分とほぼ同じ值であったことから，調査対 象者は，18歳から20歳の日本人女性を代表できる体型を 持つ集団であると考えられる。本研究に抢ける瘦身志向 「あり」の割合は調査対象者の $87.9 \%$ であが，BMI 区 分では, $17.5 \%$ がやせ， $75.4 \%$ が正常であり，肥満では ないのに瘦せたいと思う者 $(87.3 \%)$ が多かった。さら に，やせ区分の者には，BMI 16.5未満の極端なやせ （るいそう）と判定される者が 6 名含まれ，最も低い BMI 值は15.9（162.5cm，42.1 kg）であった。この極 端なやせの者は神経性食欲不振症（思春期やせ症），す なわち摂食異常の可能性が高いと考える。この疾病を抱 える者は, やせに対する異常なまでの願望を持っている のが特徵であり，言い換えれば，決して食欲がなくて食 べないのではなく，禁欲的に食べまいとする心理的な栄 養失調や，多食および隠れ食いなどの食行動異常を伴っ ている可能性がある11),12)。近年, 摂食異常のメカニズ ムについては遺伝的要因の存在することが明らかとなり， 神経系疾患の中で最も高い死亡率を占める病気として病 態解明が進みつつある13)。本研究に打いても, BMI 16.5 未満の極端なやせの状態であるにも拘らず「瘦身志 向あり」の者がいる現状は，そのまま改善されずに継続 されれば死に至ることへの認識を持たせる健康教育と, 病因解明のためのカウンセリングが必要であると考える。

本調査対象におけるやせ抢よび普通体格者の想定する 理想体重は，平均では $4.0 \mathrm{~kg}$ 少ない $46.5 \pm 4.2 \mathrm{~kg}$, 理想

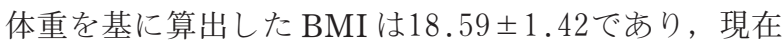
より1.59ポイント低かった。さらに，「理想体型の人が いますか」の質問に $39.1 \%$ が「る」と回答し，タレン ト，モデル，歌手などメディアに登場する約50名の名前 があがった。この人々の身体的特徵を web site, official site 等で調べてみたが， site に体重を公表していたのは モデル 1 名（身長 $169 \mathrm{~cm}$, 体重 $47 \mathrm{~kg}$ ）だけであった。こ の身長と体重から算出した BMI は16.5の極端なやせ （るいそう）で，対象者の想定する理想の BMI より更 に2.0低い体型であった。本調査に拈いて，BMI 区分が やせ抢よび正常であるにもかかわらず瘦身志向ありの者, つまり体重の誤認識が疑われる者がいることが分かった が，このような若年女性の体型の誤認識は，メディアに よる社会的な環境因子や心理因子などにより，ダイエッ 卜行動を駆り立てるものによると考える1)-3)。

身体活動指数は，BMI 区分別での有意差はなかった が，やせ区分の者の身体活動指数はやや高く，肥満区分 の者はやや低い傾向を示した。すなわち，やせの者の身 体活動性は交進して平均より高く消費エネルギーが保た
れている傾向があり，肥満に悩む多くの人は容姿を気に して消極的な行動をとるなど，体型と行動の関連を調べ た報告14）と同様の結果となった。一方，身長抢よび身体 活動指数に差がないにもかかわらず，体重および BMI に有意差が認められるということは, 摂取エネルギーに も有意差があると推察される。今後, 瘦身志向と食事摂 取状況の詳細な検討が必要であろう。

\section{2. 体重調節に関する意識と行動}

先行研究において, 体型に対して詋ったボディイメー ジを持つ者が多いことは既に報告されている15)。本研究 においても体型に対して誤ったボディイメージを持つ者 が多く, BMI 18.5未満のやせの者が，自分の体型を現 実より太めに評価している割合は71.6\%に達しており， 特に瘦身志向ありの者で, 自分の体型を太っていると誤 認識している者の割合が高い傾向がみられた。一方，瘦 身志向を持つ者のうち「減量経験がある」者は $60.9 \%$, すなわち, 肥満ではないのに自分を太っていると䛊認識 し，現在の体型に満足できずにやせ願望を持ち，さらな る減量を試みる傾向がみられた。

ダイエットの方法については, 食事に関するものが多 く出現する一方で，運動を行う者，また，運動と極端な 食事制限を併用すると答えた者もいた。減量および肥満 の治療には, 食事療法や運動などの一般的な方法から薬 や外科的な方法まで無数にあるが，食事を抜いたり食欲 を抑える薬を使用することは，健康に好なしくない影響 を与える16),17)。食事の量を減らしてやせようとするの ではなく, 食べ方にも注意を向け, ライフスタイルの変 容と継続可能な行動変容に結び付けることが大切である と考える。

\section{3. 疲労自覚症状と瘦身志向}

心身の疲労に関する主観的判定が可能である疲労自覚 症状しらべ（表 5 ）によると, 瘦身志向別疲労愁訴率で は，I群の「ねむい」「足もとがたよりない」に有意差 があり，瘦身志向の強い若年女性において，「眠気とだ るさ」に関する肉体的愁訴が顕著に高い傾向を示した。 生活時間調查における 1 日の睡眠時間は, 瘦身志向があ る者 6 時間 53 分 \pm 100 分，瘦身志向がない者は 7 時間 21 分土103分であり，瘦身志向がある者の睡眠時間は短い 傾向がみられたが有意差は認められなかった。

体型区分に提いて正常であるにもかかわらず瘦身志向 を示す者，目標としている理想体型がやせの範囲で更な る体重減少を望む者, また, ダイエット経験はないが瘦 身志向があり体重減少を考えている者の疲労愁訴が有意 に高いことなどから，スリムな身体への憧れ，体重減少 への願いは心と身体の疲労すなわち強いストレスとなっ ていると考える。

既に我々は疲労の兆候8),9) に関する報告をしているが, 本調査に抢ける若年女性の疲労自覚症状は， I > II > II 
型の精神作業疲労型で一般型ではない。特に瘦身志向が ある者にこの疲労が強いことなどから, 瘦身志向や生活 習慣などのストレスにより不定愁訴が増大し，健康を損 なう実態が明らかとなった。このようなことから，本調 査に抢ける「眠気とだるさ」の高い愁訴率は, 単なる睡 眠時間の長短ではなく, 容姿を気にしてありのままの自 分に安心感が持てず，心身の疲労を蓄積していることに 起因するものであることが推察された。このような生活 意識および生活習慣を継続することにより，注意集中の 困難や局在した身体違和などに関する疲労症状へと変化 し, さらには精神的な疲労症状へと移行していく可能性 があり，活力の低下といった健康への影響が懸念される。

\section{4．健康および食生活に関する意識}

瘦身志向のある者に自棄食い経験のある者が多い傾向 を示したように，女性特有の瘦身志向や肥満恐怖という 身体へのこだわりがダイエット行動に繋がり, 減量とリ バウンドを繰り返すウエイトサイクリングをする者が多 い。ウエイトサイクリングをするうちに，いくつもの不 定愁訴を抱え达み, 心も身体も疲弊し, 自棄食いなどの 現状破壊行動に繋がっていることが伺われる。本調査に おける瘦身志向を持つ対象者のダイエット行動もウエイ トサイクリングで, 本来必要でないことを認知すべきで ある。この状況は, 健康日本 $21 に$ 示される「心身の成長 期にあるもの」,「中等度以下の女性型肥満」,「スリム指 向の強い非肥満若年女性」, 「過激なダイエットによる短 期急速減量」などの「減量が健康上悪影響を及ぼす危険 のあるもの」に該当する ${ }^{18)}$ 。対象とした若年女性は，今 後も誤った理想体型の実現に向けて本来不必要なダイエ ットを繰り返すと推察され, 加齢をはじめ精神的問題に 起因する掑食行動異常など幾つかのリスクも加わって, 治療に対する抵抗性が高い難治性肥満へと移行する危険 性を持っていると考える。

一方，食生活に対しては「配慮している」が，「食事 時間は不規則」な者が多い傾向を示した。本調査では, 食事制限の詳細な内容は検討せず「配慮」という表現に 留めたため, 疾病, 健康抏よびダイエット等, 複数の条 件に対する「配慮」が混在していることも考えられるの で，今後検討の必要があろう。

肥満者の割合は, やせの者と比較すると 10.4 ポイント 低い出現割合ではあったが，肥満 2 度 $(30.0 \leqq B M I<$ $35.0 ） 2$ 名, 肥満 3 度 $(35.0 \leqq \mathrm{BMI}<40.0) 2$ 名が含ま れ, 瘦身志向の「ない」者も 1 名（BMI32.5）いた。 肥満に関しては, 空腹感を制御するホルモン (Leptin) が遺伝的に欠如していて，自分の意思のみでは食欲を制 御することができないために太っているという人が存在 することが報告されている。今後さらに肥満のメカニズ ムは解明されていくであろうが, 肥満者には, 健康の維 持 ·増進, 生活習慣病の予防の上で, 体重を適正にコン トロールすることが大切であることを健康教育の中心課
題としていく必要があると考える。

本調査に打渃年女性は, BMI を基準とする体型 区分では, やせおよび正常であるにもかかわらず瘦身志 向のある者が $92.2 \%$ と多く, 誤った理想体重の実現に向 けてのウエイトサイクリングで精神的な疲労症状が高い 傾向を示した。健康を維持・増進し, 将来も生活の質 （QOL）の高い生活を送るためには，本来必要でないダ イエット行動の継続的な変容に関する教育を行うことが 重要であることが示唆された。

\section{要 約}

近年の若年女性においては, Body Mass Index (BMI) を基準とする体型区分ではやせおよび正常でありながら， 特有の体重調節意識を持つ者が増加している。本研究で は，若年女性の瘦身志向が心身に与える影響について， 食行動と疲労自覚症状をもとに明らかにすることを目的 とした。

1 ） BMI を基準とする体型区分によるやせ, 正常, 肥満の割合は，順に $17.5 \%, 75.4 \%, 7.1 \%$ であっ たが，瘦身志向がある者は全体の $87.9 \%$ に達した。 特に瘦身志向がある者の中で, BMI が「やせ」と 「正常」の者の割合は $92.2 \%$ あった。

2 ) 瘦身志向のある者は, $60.3 \%$ が自分の体型を「太 っている」とイメージし， $60.9 \%$ がダイエットをし たことがあり, 瘦身志向の有無の間には, それぞれ 有意差が認められた。

3 ) 自棄食い経験は, 瘦身志向がない者 $(38.0 \%)$ に 比較して, ある者 $(53.6 \%)$ が有意に高い割合を示 した。

4 ) 疲労愁訴率合計は, 瘦身志向がない者 (19.7\%) に比較して，ある者 $(25.9 \%)$ で有意に高かった。 疲労自覚症状 I 群の「ねむい」,「足もとがたよりな い」では, 瘦身志向のない者に比較して, ある者が 有意に高い割合を示した。

\section{文献}

1）「日本で強迫観念に」ブラジル人モデル，拒食症で死亡, 朝日新聞 $(2006 / 11 / 18)$

2) やせ過ぎモデルはファッションショー出場禁止 摇れる ファション界, ロイター通信社 $(2006 / 09 / 19)$

3）やせ過ぎモデル禁止 マドリード市決定に反発, 波紋広 がる，毎日新聞 $(2006 / 9 / 16)$

4）厚生労働省: 平成15年国民健康 - 栄養調査報告, 第一出 版 (2006)

5）亀崎幸子, 岩井信夫 : 女子短大生の体重調節志向と減量 実施抢よび自覚症状との関連について, 栄養学雑誌, 56, 347〜358（1998）

6）江澤郁子：ダイエットと骨粗鬆症, 母子保健情報, 40 , 40〜43（1999）

7） 21 世紀に抢ける国民健康づくり運動（健康日本21）, 厚生 省 (2000)

8）重田公子, 笹田陽子, 鈴木和春, 樫村修生 : 青年期女性 
の減量のための食事制限が健康に与える影響, 栄養学雑誌, 63-5，252（2005）

9）重田公子: 青年後期女性の疲労の徵候と食行動, 東横学 園女子短期大学紀要, 30, 81 90（1995）

10）重田公子: 青年期の女性の食と健康に関する意識, 東横 学園女子短期大学紀要，32，225～254（1997）

11) Palmer,R.L : Helping with Eating Disorders, John Wiley （2000）（佐藤裕史訳, 摂食障害者への援助, 金剛出版, 2002)

12）宮崎由子, 緒方智子 : 摂食障害を示す女子大生の心理的 特性と栄養状態評価, 栄養学雑誌, 64-1，31～43（2006）

13) Samuels. A. (ed.) : Psychopathology. Contemporary Jungian Perspective. H.Karnac Books Ltd. (1974)

14）末松弘行: 神経性食欲不振症の診断基準, 神経性食欲不 振症調查研究班平成 3 年度研究報告書, 厚生省 (1991)
15）田中恵子，池田順子，東 あかね，中澤敦子，中谷素子， 入江祐子, 松村淳子, 杉野 成: 20 歳代女性住民に打怕 やせ・普通体格のダイエット実践者の生活習慣 - 平成 10 年 度京都府民健康づくり · 栄養調査より -, 栄養学雑誌, 632, 67〜 74 (2005)

16）厚生労働省医薬局 · 監視指導 · 麻薬対策課/食品保健部 · 新開発食品保健対策室 : 中国産ダイエット食品による健康 被害事例，医薬ジャーナル，38-09（2002）

17）厚生労働省：中国製ダイエット用健康食品（未承認医薬 品）による健康被害事例, 健康被害情報 - 無承認無許可医 薬品情報（2006）

18) Blackburn, G.L., Rosofsky, W.: Marking the connection between weight loss, dieting and health-the $10 \%$ solution, Weight Control. Digest, 2 , 121-127 (1992) 